\title{
FOR WESLEY STURGES: ON THE TEACHING AND 'STUDY OF LAW
}

\author{
GRANT GLLMORE $\dagger$
}

During the academic year 1941-1942, toward the end of the fall term, several second and third year students, of whom I was one, conceived the odd idea that our legal education would not be complete without a course in the common law forms of action. This antiquarian project afforded us, no doubt, a pleasant distraction from the great and terrible events which threatened to overwhelm us. But the official schedule of courses and seminars was of no help to us. Then, as now, the common law forms of action did not make the grade in the forward-looking Yale curriculum.

We decided to ask Wesley Sturges to offer such a course in the spring term. When our delegation waited on him his attitude was one of grave courtesy and mild amusement : he neither commended us for our historical interest, nor castigated us for having lost touch with reality. He would, he said, offer the course if a sufficient number of students signed up. He did not point out to us that, in addition to his having a full teaching schedule for the spring term, he had committed a large portion of his time to activities on behalf of both the state and federal governments in connection with what was called, before Pearl Harbor, the defense effort. The course was announced, about twenty students signed up and, through the catastrophic spring of 1942, Wesley labored patiently with us as we canvassed the mysteries of replevin, trover, detinue, and debt.

During the same academic year I was enrolled in Wesley's course in Credit Transactions-the course which was both the terror and delight of a generation of students at the Yale Law School. During the spring term the class in Credit Transactions decided to express its appreciation by presenting a gift to the instructor: in twenty-five years of association with the School, as a student and a member of the faculty, I have never heard of any other occasion on which such a thing was done. A collection was taken up, a committee was appointed to purchase an appropriate token and, at the beginning of one session the ceremonial presentation was made. ${ }^{1}$ Wesley acknowledged the gift and briefly thanked us. "There is," he said, "only one reason why I teach law : I enjoy it."

$I$ shall engage in a somewhat lengthy attempt to reconstruct the general atmosphere of the time as well as the particular situation of the Yale Law School. The background throws some light on the work Wesley chose to do and on the intensely personal quality of his teaching.

†William K. Townsend Professor of Law, Yale Law School.

1. The token was some object of domestic use-perhaps a box for cigarettes-which was, or could be plausibly described as being, in the shape of a barrel-wagon. On barrclwagons, see Gamson v. Pritchard, 210 Mass. 296, 96 N.E. 715 (1911), reprinted inv StuncEs, Cases on Credit Transactions 231 (4th ed. 1955). 
Law teaching, as it has developed in this country, is a strange business. Almost the only proposition on which its practitioners agree is that law teachers are not, and should not be, engaged in doing what teachers have always been supposed to do.

In the elementary grades the principal function of teachers is to communicate to children the essential mysteries on which our civilization depends: how to read, how to write, how to figure. It is as hard to understand how small children can be trained to perform these complex intellectual operations as it is to understand how man ever succeeded in civilizing himself in the first place. On the level of so-called higher education, however, the teacher's function, as it is commonly understood, is a simpler one. He is a pipeline through which the knowledge and, hopefully, the wisdom of the past is transmitted. To some degree he is also supposed to act as a purifying agent for the raw materials that he carries; he is to simplify what is difficult, to reduce chaos to order, to explain the true meaning of things.

It has been the considerable orginality of the American law schools to have developed, particularly during the generation to which Wesley Sturges belonged, a style of teaching which represents the negation of both the transmitting and the purifying functions of teaching. The late Karl Llewellyn put the matter aptly when he remarked in the introduction to his casebook on Sales: "I do not conceive it to be a teacher's duty to let the true light shine."

The peculiar style which established itself in the leading American law schools after 1920 may be explained as the resultant of a number of diverse forces working at cross-purposes.

We accept as an article of faith that the great mutation in American law teaching came with the adoption of the case method in law schools throughout the country. We assume, without giving much thought to the question, that in the days before law was taught by the case method, law professors gave what we call lectures to their students. In their lectures they aimed, no doubt, at a rational and coherent organization of subject matter: they collected the leading cases, analyzed them, and distilled from them the true doctrine and the correct rule.

We are told that the proponents of case method teaching thought of their invention as merely a better way of doing what the lecture system had sought to do. The end result was still to be that the student would arrive at an understanding of true doctrine and correct rule. However, instead of a merely passive acceptance of authority, there was to be, on the student's part, an active labor of learning. From the study of a carefully selected sequence of cases, the student was to move, by a process of inductive reasoning, toward a formulation of doctrine and rule. The teacher's function, apart from his initial selection of the appropriate cases, was to be a relatively passive one-like that of a trial judge who is forbidden by the local rules of procedure from commenting on the evidence which has been put before the jury. It is, however, reasonable to

2. Llewellyn, Cases and Matertals on Sales xwii (1930). 
assume that the purest of case method teachers, like the purest of trial judges, found ways of communicating his own opinions to his captive audience.

The period of transition from teaching by lecture to teaching by cases ran from about 1890 to about 1920. During the same period another event of capital importance in our legal history took place, also under the auspices of the law schools. I refer to the extraordinarily rapid elaboration of the first com prehensive legal literature in this country.

Before this period the profession of law book writer and the profession of law teacher appear to have been separate ways of life. Most of the treatises which began to appear in some profusion after 1850 were clearly designed as aids to the practicing lawyer in keeping up with the mounting flood of cases and statutes. The authors, apart from the occasional scholarly judge or practitioner who wrote as an avocation, seem to have been hacks who worked under contract with the law book publishers, writing this year a treatise on corporations, next year a treatise on bailments, and the year after that a trea. tise on negotiable instruments. "Hacks" is too severe: some of the books were very good indeed and even the poorer ones no doubt served a tseful purpose. But what was produced was a literature of modest ambitions and limited objectives, whose inspiration was practical or commercial, not theoretical or jurisprudential.

After 1890 the law school faculties became the principal source of a new literature-quite different in character from the old. From modest beginnings the law school-sponsored law reviews grew until they quite displaced the professionally edited journals of the previous period. The spate of learned articles became a spate of learned treatises, with the number of volumes increasing by geometrical progression from edition to edition. By 1920 or thereabouts the disparate materials of our common law system had been organized and illuminated by a comprehensive commentary, both scholarly and theoretical, of a kind which could hardly have been imagined a generation earlier.

There may appear to be an element of paradox in the fact that the pioneers of case-method teaching were also the architects of the new literature. Case method teaching eschews formal statement and didactic presentation. If focuses on particular fact situations, not on general theory; it tends to become unsystematic, confused, and disorganized; it invites the student to make up his own mind, to build his own system, to work for his own insights. But all the things which the first exponents of case method teaching refused to do in their classes, they did in their articles and books. Thus the formal statement and didactic presentation which the student would not receive from Professor $\mathrm{X}$ in class could be conveniently run down in the law library by consulting the publications of Professor $\mathrm{X}$ and his colleagues.

Each generation revolts against the work of its predecessors. The great accomplishment of the American law schools during the period which runs from 1890 to 1920 appears now to have been the production of an immense literature of orderly and systematic statement. In the main the prevailing intellectual mood which characterized this literature was a confident belief in the rational 
structure of the legal system, in the possibility of logical progression from premise to conclusion, in the relationship between the rule of law and the result at law. We may assume that, after the hiatus of World War I, a countervailing mood would at all events have asserted itself. The particular form which the new mood assumed was determined by the intellectual currents of the time: it came to be known as Legal Realism and carried with it the most original and powerful minds of the period between the two World Wars.

The etiology of a major intellectual movement defies precise investigation: we can get at one aspect of the truth only by ignoring others of equal relevance. I have suggested elsewhere that the Realist movement was the academic formulation of a crisis through which our legal system passed during the first half of this century. ${ }^{3}$ Under this hypothesis, which seems to me both plausible and incomplete, Legal Realism obscurely reflected the breakdown of an overburdened and no longer workable case-law system and its gradual replacement by a system of statutory and quasi-statutory law. ${ }^{4}$ On the level of jurisprudential theory, Realism sought its justification outside the range of narrowly conceived theories about the nature and process of law. The emergence of Realism as a distinctively American pattern of legal thought was contemporaneous with the emergence in this country of the so-called social sciences as a novel intellectual discipline and a major subject of study. From the adepts of the newly named sciences of psychology, anthropology, and sociology, there poured forth revolutionary insights into the nature of man and society. The first generation which follows in the wake of a revolution, political, social, or intellectual, is buoyantly convinced that the truth-the whole truth-now lies within its grasp. The wisdom of uncertainty comes only with time and repeated demonstration of error. In the 1920's the social sciences offered the bright promise of a brave new world, as yet untarnished by reality. It was to the hypotheses of the psychologists, the anthropologists, and the sociologists that the lawyers, themselves untrained in any discipline but law, turned for the intellectual weapons with which they hoped to destroy the work of their predecessors.

The literature of the Realist period, from 1920 to 1940, was significantly different from the literature of the preceding period. Its purpose was not so much the organization of truth as the demonstration of error. Its tone was hostile, attacking, controversial. To the massive multi-volume treatise there succeeded the critical law review article, which demonstrated the inadequacy of past analysis without bothering to propose a more adequate analysis for the present. It was a time of intellectual ferment, of excitement, and of discovery.

As teachers, the Realists laid hold of the pedagogical innovation of their predecessors-the case method-and turned it against its inventors. The case method, as we have said, seems to have been put forward as a way of leading students to an understanding of the logical consistency and the formal completeress of the law's doctrinal structure. The Realists, adopting the method,

3. Gilmore, Legal Realisn: Its Cause and Cure, 70 YaLE L.J. 1037 (1961).

4. The Restatements of Law are examples of quasi-statutory law. 
used it to demonstrate that the doctrinal structure did not even exist. In an. alyzing the individual case, they probed for the discrepancy between the stated fact and the announced doctrine. In selecting sequences of cases for their casebooks, they looked for the hidden inconsistency, the latent contradiction, the misapplication of the general proposition. The law student, applying the process of inductive reasoning to the collections of cases which were now being set before him, could arrive only at chaos.

Among the law schools Yale became the stronghold of the young Turks, intent on revolution, while Harvard remained the bastion of conservatism. That this should have happened reflects the great strength of the extraordinary group of men who comprised the Harvard law faculty during what is often, and rightly, referred to as a golden age in the history of that school. Those men, revolutionaries in their own time, had in a single generation raised the level of American legal scholarship to unprecedented heights and transformed the nature of American legal education. Still vigorous and active, they naturally sought to conserve their hard-won ground. Yale, on the other hand, was emerging from a long period of decline and weakness. It had no great tradition to bear it up or weight it down. It was free to experiment, to challenge, to innovate. Professor Corbin has told us of the School's reawakening and resurgence under the leadership of Dean Swan. A law school's greatness does not depend on its faculty alone, but without an able faculty greatness is an unlikely issue. The historian who traces the make-up of the Yale Law School factity through the period after World War I will be tempted to conclude that the program of faculty recruitment was carried out under divine guidance. In particular, the names which make their appearance year by year in the successive catalogues comprise a nearly complete roster of the Legal Realists. When those who were associated with the School during that period describe it for us, we cannot but receive the impression of an overflowing vitality, an atmosphere of exhiliration, even of exaltation. It was during this time of heady excitement that Wesley Sturges joined the faculty with which he was to remain associated, as Professor and as Dean, until his retirement in 1961.

Wesley was not much given by nature or by habit of thought to theoretical speculation or the building of systems. So far as his published work goes, he took no part in the long debate on the nature of law and the judicial process which accompanied the Realist controversy. Nor did he turn for inspiration to the novel approaches or the new techniques for investigation being developed in the social sciences which so many of his colleagues found attractive. Shunning the broad and misty reaches of jurisprudence and disinclined to seek sal vation beyond the traditional frontiers of the law, he devoted his remarkable talents to the precise and technical analysis of legal concepts. Among the notable figures of the Realist movement, in whose ranks he must surely be counted, Wesley stands out as the preeminent analyst, the lawyer par excellence.

In the area of commercial law and creditors' rights, which was the principal subject of his teaching, his work was in large part negative or destructive. He was engaged in exposing fallacies and in demonstrating the inadequacy of over 
generalized statement and underanalyzed concept. But Wesley's work, taken as a whole, was not merely destructive. It seems to have been a characteristic of the Realists that they were builders as well as destroyers. What they sought to destroy was what they conceived to be an oversimplified and overoptimistic view of the working of a case-law system. Some, like Karl Llewellyn, went on to reformulate broad areas of law as statutory draftsmen. Others, like William O. Douglas and Thurman Arnold, gave up the teaching of law to engage in its administration. Wesley was like these and others. Early in his career he came to see the arbitration process as a fruitful alternative to the judicial process. There is a symbolic rightness in the fact that Wesley published in the same year (1930) not only the first edition of his case book on Credit Transactions but also his massive treatise on Commercial Arbitrations and Awards.

Although the field which Wesley christened Credit Transactions remained throughout his career the major interest of his teaching, he did not write extensively about it. Apart from the successive editions of his casebook, the only major contribution was the article on Legal Theory and Real Properiy Mortgages which appeared in the Yale LAw Journal in April of 1928. The article exemplifies Wesley's severely analytical version of Realism: urbanely skeptical, corrosively disintegrating.

The theme of the article is the celebrated distinction between the title theory of mortgages and the lien theory. The conclusion is that the classification of states in accordance with the title theory, the lien theory, or an "intermediate" theory has nothing to do with the results reached by the courts. The first part of the article consists of a series of quotations from the standard authorities. These quotations, which describe the conceptual differences between the two theories, are then subjected to a rigorous semantic analysis. The analysis, carried out with delightful good humor, is designed to demonstrate the hidden ambiguities, the internal contradictions, and the essential meaninglessness of the propositions set forth. Having successfully disposed of the commentators, the article then proposes to "turn to the reported cases and examine some of them in the light of the alleged division of states according to the theories in question." This is done by examining half a dozen situations in which title theory states should reach one conclusion and lien theory states should reach the opposite conclusion if indeed the state's approach to the theoretical nature of the mortgage interest determines decision. The conclusion in each instance, supported by abundant case citations, is that there is no discernible correlation between theory and result. The article then takes up the possibility that "in a given state a given theory permeates, at least by-and-large, its whole mortgage structure,"7 so that some consistency might be found in the decisions from a single jurisdiction even if no consistency can be found on a broader scale. This possibility is examined in the light of a series of cases decided by the Supreme

5. 37 YALE L.J. 691 (1928). The article was written ir collaboration with Samuel O. Clark, a third year student and a member of the Board of Editors of the Journal.

6. Id. at 704 .

7. Id. at 709 . 
Court of North Carolina: both the cases and the state, we are assured, having been picked "at random." The reader who works his way through the next several pages will realize that consistency was not the strong point of the North Carolina court. The article concludes with the clearest expression I have found of Wesley's fundamental theoretical-or, if you will, antitheoretical-position:

We are certain, after reviewing the reported opinions of the courts in some of the other American states, that North Carolina is not "anomalous" or in an exceptional "confusion" concerning its theory (i.e., theories) of a mortgage. We are reluctant to refer to the situation as one of "confusion" because the opinions of the North Carolina court were approached with a feeling that, true to life generally, questions in mortgage law are many and complex and that a court confronted with a concrete case with its live parties presenting conflicting claims is likely to be influenced by the particular case to the prejudice of any simple generalization, general legal principles, legal theory or conception of "a mortgage," and that the symmetry of any doctrine or conception will be lost in that "wilderness of single instance." Unless it is postulated that the establishment and preservation of such a symmetry is the primary, fundamental, far-reaching function of the court we do not criticize it for its "variations."

If there are some rules of mortgage law which are uniform throughout the states, two, three or more different theories to the contrary notwithstanding, and if a given state will use or refrain from reciting a given theory in a given case depending upon whether it does or does not, why then, do these theories recur in the opinion? Certainly the text writers have not made these several theories out of whole cloth. At least for the most part they are recited in opinions of the judges every now and then and more or less at length.

Without presuming to declare why judges behave like judges, we do submit that the writing of opinions couched in one or more terms which are more, rather than less, abstractions, in terms of generalizations, general legal principles, legal doctrine or legal theory, is a problem involving the functions of language. Without insisting that there is an exact delineation in the two concepts, we believe, however, that the words reporting the theories, doctrines and generalizations which are under consideration are not used as symbols designed to be descriptive, but rather to be emotive. They are "one word more" in soliciting approval, in urging plausibility, for a particular judgment. ${ }^{8}$

The article ends with two fairly lengthy quotations from Ogden \& Richards, The Meaning of Meaning, whose burden is that words are dangerous things which "may come between us and our objects in countless subtle ways, if we do not realize the nature of their power." A final footnote to the article, appended perhaps as an afterthought, returns to the attack:

Limitations of space have prevented a critical consideration of the sounds "a mortgage," "the mortgage," "the ordinary mortgage." It is clear, however, when the several fact-transactions are identified which are included under the term "mortgage," "the mortgage," or "the ordinary mortgage" in common usage, that there are mortgages and mortgages not only as a

8. Id. at 713-14.

9. Id. at 715 . 
matter of difference in fact-pattern but also in matter of court decisions and in matter of recital of legal theory; that in the same type of case a given court may write of "lien theory" concerning one type of fact-pattern and of "title theory" concerning another fact-pattern although the issue is the same in both cases. The decision may be the same; it may not be the same. These matters are left to a later consideration. ${ }^{10}$

The jurisprudential attitude illustrated by this article is surely a hopeless and despairing one. Theory is a dead end, doctrine is absurd, rules of law are merely meaningless sequences of words whose function is not "descriptive" but "emotive." At an earlier point in the article the author states his belief to be that a court-any court- "uses or refrains from using one theory in one case and uses or refrains from using that theory in another case, depending on the judges' sense of convenience and the matters which stimulate them in the particular case."11 The "judges' sense of convenience" and "the matters which stimulate them" can hardly be made into tools for analysis or prediction. There is, to be sure, an obscure reference in the final footnote, quoted above, to what are called "fact-transactions" and "fact-patterns" and a suggestion that the "identification" of these transactions and patterns might lead to something." "These matters," however, are "left to a later consideration"-but, from Wesley's pen, that "later consideration" was never forthcoming. It cannot be surprising that there was no sequel: the article stands as a lonely monument, an ultimate expression of disbelief.

I do not believe that the attitudes expressed in this article were, on Wesley's part, passing fancies. They were the permanent landmarks of his intellectual life. At the end, as at the beginning, his response was an uncompromising: Non credo.

During my years as a student at the Law School, my classmates and I received instruction from many extraordinary men: from Wesley's classes we might go to those of Arthur Corbin or of Underhill Moore or of Harry Shulman, to name but three. It seemed to me at times that our mentors were engaged, in a manner of speaking, in fishing for our souls-each in competition with the others. We were successively persuaded by the mellow wisdom of Arthur Corbin, by the jurisprudential theories of Underhill Moore, by the enigmatic subtleties of Harry Shulman-but perhaps most of all by the devastating analysis which Wesley Sturges offered us.

The virtuosity of Wesley's classroom technique is legendary among all his students. His wit, which seemed never to fail him, was razor-keen. His fertility in inventing hypothetical variations appeared to be inexhaustible. His ingenuity in playing devil's advocate was unbelievable. A not infrequent sight in Wesley's classes, which the rest of us followed with a barely concealed delight, was that of the learned and consciously brilliant Editor-in-Chief of the Yare LAw JoURNaI falling ignominiously into helpless contradiction with himself as he

10. Ibid.

11. Id. at 709.

12. Id. at 715 . 
shifted his position back and forth, back and forth, following the will-of-thewisp logic of the imperturbable instructor who, with a wave of his magic wand, would transform the indisputably white into the incontrovertibly black-and back again. I should add that all this prestidigitation was carried out without the slightest suggestion of cruelty toward the victim at whose expense these mystifying tricks were performed. It was not, perhaps, an altogether enjoyable experience to the victim while it was going on but it was, unquestionably, an instructive one. And no one ever doubted that Wesley was as wholeheartedly devoted to his students as his students were to him.

What did Wesley teach us? He taught us, in a way that none of us will ever forget, something-indeed, a great deal一about the use and the uses of words. I can think of few things that are more central to the lawyer's craft and art. $\mathrm{He}$ taught us to be forever on our guard against the slippery generality, the received principle, the authoritative proposition. He taught us to trust no one's judgment except our own - and not to be too sure of that. He taught ts how to live by our wits. He taught us, in a word, how to be lawyers.

I think of Wesley as having been, intellectually, a tragic figure. He came early to a conception of the law which was cold, bleak, and barren-like a winter landscape. There was no comfort, no solace, no softness in what he saw. From the rigors of his position he sought no escape. He pursued inexorably, with all the power of a finely-tuned mind, the consequences which followed from his initial premise. The consistency for which he sought lay within himself : he had, as few of us do, the courage of his desolate convictions. 